\title{
THE EARLIEST KNOWN FOSSIL ANT \\ (FIRST SOUTHERN HEMISPHERE MESOZOIC RECORD) (HYMENOPTERA: FORMICIDAE: MYRMECIINAE)*
}

\author{
By Carlos Roberto F. Brandão ${ }^{1}$, Rafael G. Martins-Neto 2 , \\ and M. Aparecida Vulcano ${ }^{3}$
}

Social insects are scarce in Cretaceous deposits. Sphecomyrma freyi Wilson \& Brown (1967) was the first fossil ant assigned to the Mesozoic. The wingless holotype and paratype were found embedded in amber at Cliffwood, New Jersey, U.S.A. (Magothy Formation). This formation was at the time referred to the lower part of the Upper Cretaceous (Turonian-Coniacian), presumably deposited not long after mid-Cretaceous times, about 100 million years ago (Wilson et al., 1967). S. freyi was described as the typespecies of the only genus of a new subfamily of Formicidae, Sphecomyrminae. These deposits have been recently redated as Santonian or even early Campanian, circa 80 million years ago (Zherikhin, 1978 apud Dlusskyi, 1983).

Dlusskyi (1975 apud Dlusskyi, 1983) described Cretomyrma and Paleomyrmex, respectively, from a worker and a male, found in fossil tars at Yantardakh, Tamyr Peninsula (extreme north-central Siberia), both of approximately the same age as Sphecomyrma freyi (Late Santonian) and assigned to the Sphecomyrminae. Four other Cretaceous genera, described in the same publication (Cretopone, Petropone, Archaeopone and Dolichomyrma) were found in southern Kazakstan (Kzyl-Dzhar) in considerably older beds (Turonian). The first three genera named were originally considered to belong to the extant subfamily Ponerinae.

Dlusskyi (1983) studied 13 very well preserved impressions tentatively interpreted as ants, found in the Ten'ki district of the Magadan region (extreme eastern Siberia), Ol'skaya Formation

\footnotetext{
*Contribution of "Projeto 242-Cretácico de Latinoamérica, IUGS-UNESCO" 'Museu de Zoologia da Universidade de São Paulo, caixa postal 7172, São Paulo, SP, Brasil, 01051

${ }^{2}$ Departamento de Paleontologia e Estratigrafia, IG-USP, caixa postal 20899, São Paulo, SP, Brasil, 01498

${ }^{3}$ rua dos Pessegueiros 144, São Paulo, SP, Brasil, 05673

Manuscript received by the editor June 25, 1989.
} 
(Cenomanian) in a tributary of the Nil River, on the upper valley of the Arman' River. He reinterpreted the systematic position of the genera, elevating the Sphecomyrminae to family level, to include Sphecomyrma, Cretomyrma, and Paleomyrmex. He proposed for the Turonian genera and for new Cenomanian ones (Armania, Armaniella, Pseudoarmania and Poneropterus) a new family of Formicoidea, Armaniidae. Dlusskyi questioned that $S$. freyi types are workers from an eusocial species. His arguments are based on antennal and mandible structure; the tips of the antennal funiculi would be too far removed from the mandibles to permit brood manipulation or to engage into trophallaxis with their larvae. The short, wasplike mandibles "indicate that these insects did not build true nests, and could have used only already pre-existing hollows."

Wilson (1985a) described a second species of Sphecomyrma, $S$. canadensis, from Alberta, Canada. Based on neontological criteria, he said: "It is difficult to find sound reasons for separating most of them [Dlusskyi's genera] from Sphecomyrma, providing we limit ourselves to the same criteria applied to contemporary genera and tribes. There seems to be little justification for placing them in a separate family, the Armaniidae, as suggested by Dlusskyi."

Dlusskyi (1987) redefined the Sphecomyrmidae, after describing Baikuris from a well-preserved male and male fragments in resin at Lake Taymyr, Baykura-Neru Bay, in an Upper Cretaceous deposit. In the paper he reiterates his early opinion that "the most logical and solidly founded idea would seem to be that Sphecomyrmidae were not the ancestors of the ants, but instead were an evolutionary dead-end group that left no descendants. The direct ancestor of both the Sphecomyrmidae and the Formicidae were the Armaniidae."

Wilson (1987) reinterpreted again all Cretaceous ant species then described, arriving at a wholly different conclusion from that of Dlusskyi. He formally synonymyzed the Sphecomyrmidae and (tentatively) the Armaniidae under Formicidae. Sphecomyrminae would include only Sphecomyrma (with which most of Dlusskyi's genera are synonymyzed) and Cretomyrma Dlusskyi. Petropone and Cretopone remained incertae sedis within the Formicidae. Furthermore, Wilson interpreted the three phases represented among the Cretaceous fossils as queens, workers and males of eusocial species. He criticized Dlusskyi's statements contrary to eusociality in Cretaceous formicoids saying that although direct evidence is lacking, 
nothing in their observable anatomy would preclude their having cooperative brood care, overlap of adult generations and reproductive division of labor. He showed that the wingless sphecomyrmine females have abdomens proportionately closer in size to modern ants workers than to the wingless reproductive females of modern nonsocial wasps. Moreover, these insects could also have constructed nests in soil, rotting wood or arboreal cavities.

Jell \& Duncan (1986) described Cretoformica explicata from a Lower Cretaceous Koonwarra fossil bed impression, interpreted as a winged male ant, encountered in a road cutting south of Leongatha on the South Gippsland Highway, Victoria, Australia. The paleoenvironment indicated by the invertebrate fauna at this bed is a shallow, semi-isolated body of water marginal to a shallow freshwater lake with periodic, probably seasonal, replenishing of the fauna from the lake and periodic mass-mortality of the isolated fauna. The authors interpreted the impression as a winged male ant based on the fore wing venation, body structure and leg form, notwithstanding a number of critical features (details of head, the petiole region, mouthparts and genitalia) are not available. Accordingly, this fossil has not been definitively assigned to any extinct or living formicid subfamily, although the observable morphology was considered suggestive of the Australian Nothomyrmeciinae. In fact, Wilson (pers. comm.) believes that this fossil could not be assigned to Formicoidea or any other particular aculeate group.

Data on Eocene fossil ants are even scantier (Wilson, 1985a). Most ant fossils came from other Cenozoic deposits, formicoids being one of the most abundant insects in more recent Tertiary formations (revisions in Burham, 1978; Carpenter \& Hermann, 1979; see also Baroni Urbani, 1980a, 1980b, 1980c, 1980d; Wilson, 1985b, 1985c, 1985d, 1985e; Baroni Urbani \& Wilson, 1987).

The phylogenetic system of the Formicidae was profoundly affected by the discovery of the fossil Sphecomyrma and by the rediscovery of the living Nothomyrmecia macrops Clark by Taylor (1978). The latter, to illustrate his hypothesis, published a phylogenetic diagram in which the Sphecomyrminae, by virtue of the presence of a metapleural gland and of supposed true sociality, are represented as the stem of both the poneroid and formicoid complexes (sensu Taylor, after Brown, 1954). Lutz (1986) improved the figure of the formicoid complex, while discussing the phylogenetic 
position of his new Eocene fossil subfamily Formiciinae.

Wilson (1985a) considered the Upper Cretaceous to the Middle Eocene the most crucial time frame to understand the key events of ant evolution. However, the Santana Formation, Araripe Basin, state of Ceará, Brasil, dated as Lower Cretaceous (Albian-Aptian, between 112 and 100 million years old) has yielded one of the richest Lower Cretaceous insect assemblages of the world, including a fossil ant found at the Tatajuba Farm, near the city of Santana do Cariri (Santana Formation-Crato Member) described below.

The Araripe Basin is a sedimentary complex extending along the borders of the states of Piaui, Pernambuco and Ceará, in northeastern Brasil. Below we give a summary of the pertinent stratigraphy, according to Martins-Neto \& Kellner (1988):

Exu Formation: fluvial sandstones of Albian age;

Santana Formation: Upper Aptian age (local stage Alagoas):

Upper Unit-Romualdo Member (carbonate and marls)

Middle Unit-Ipubi Member (evaporites)

Lower Unit-Crato Member (fine-grained limestone);

Missão Velha Formation: sandstones and shales with intercalated pyrobituminous levels (local stage Bahia, Lower Cretaceous);

Brejo Santo Formation: pelites alternating with reddish and white shales of probable continential origin (local stage Dom João, Upper Jurassic);

Cariri Formation: basal unit of the sequence, deposited on the crystalline basement. Composed of conglomerates and conglomeratic sandstones (Lower Paleozoic) (see map, columnar section and Pangeographic reconstruction in Fig. 1).

The Santana Formation, a thick sequence of limestones and shales outcropping on the Araripe Plateau, thought to have been deposited in a large, virtually landlocked lagoon, contains a rich and well-preserved insect fauna. It is the richest stratigraphic unit, where the most diverse fossil types have been found (for instance foraminifers, echinoderms, lamellibranchs, gastropods, plants, fishes and

Fig. 1. A. Araripe Basin-geologic map modified from Lima (1984). B. Local geographic map. Arrow indicates type locality. C. Columnar section of the Santana Formation; modified and simplified from Lima (1978). D. Paleogeographic situation of South America, at Lower Cretaceous time; modified from Popoff (1988). 

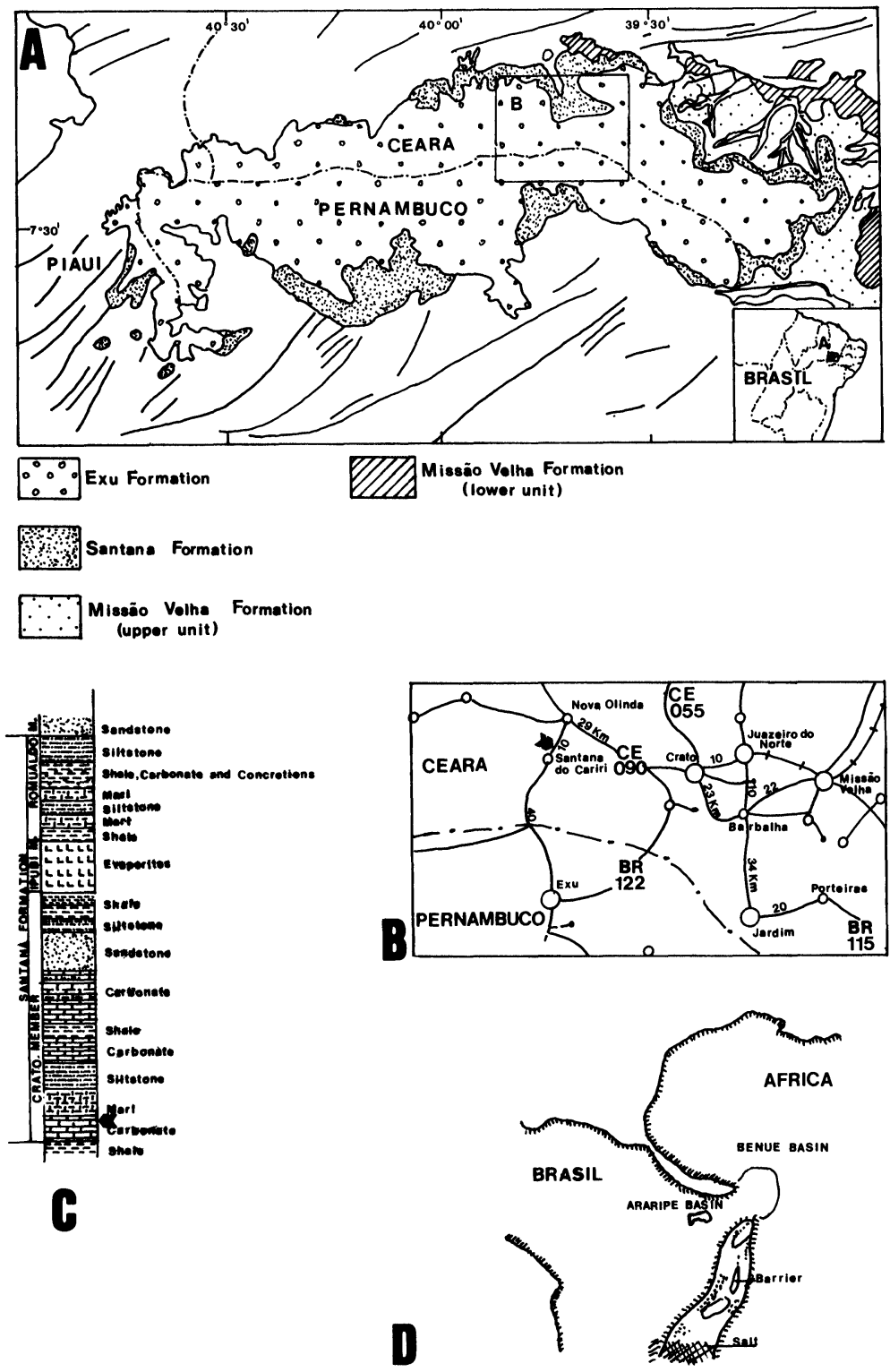
reptiles-crocodiles, chelonians, dinosaurs and pterosaurs). New specimens of Crocodylia have been recently discovered (Kellner, 1987), as well as new Pterosauria (Kellner \& Campos, 1987a; Unwin, 1988) and the first record of a brachyuran decapod (Martins-Neto, 1987a).

In the Crato Member, the lowest unit of the Santana Formation, where the specimen here described was found, an avian feather was recently discovered (Martins-Neto \& Kellner, 1988) as well as an anuran (Kellner \& Campos, 1987b), fishes, plants, a scorpion (Campos, 1986), spiders, arthropod and medusoids tracks and a very diversified insect fauna (Martins-Neto, 1987b).

The following insect orders have already been identified: Neuroptera (Myrmeleontidae, Ascalaphidae, Nemopteridae, Chrysopidae, Sisyridae, Nymphidae and Berothidae), Raphidioptera, Megaloptera, Blattodea, Coleoptera, Diptera, Ephemeroptera, Hemiptera, Homoptera, Lepidoptera, Odonata, Plecoptera, Psocoptera, Trichoptera, Mecoptera, Isoptera, Dermaptera, Caelifera, Ensifera, Phasmatodea and Hymenoptera. Many hundreds of new forms have been described, but thousands of insect specimens are still to be studied; from what surely is one of the greatest paleontological assemblages in the world from Cretaceous times.

The age of the Santana Formation was well established through the microfloral analysis carried out by Lima $(1978,1979,1981$; see also Lima \& Perinotto, 1984; Campos \& Kellner, 1985), who dated the unit as Aptian and concluded that the prevailing climate was hot, tending to arid, indicating a shallow fresh water lacustrine depositional environment, with no evidence of marine influence, unlike the Upper unit (Romualdo Member).

The only ant fossil found, though well preserved and with little apparent distortion, was very much embedded in the sediment and thus only its dorsal aspect is partially visible. Important features could not be studied, such as mandible and clypeal structures, compound eye and ocellus position, antennal insertion, trunk structure and numbers of tibial spurs. The apparent lack of spurs, wings, wing impressions or even a trace of a wing-bearing structure might be of interest, as will be discussed later.

We treated the external borders of the specimen with diluted HCL, trying to enhance the outlines on pieces considered important, such as the funicular segments and the femora-tibial articulations. 


\section{SySTEMATICS}

Cariridris Brandão \& Martins-Neto, new genus

Generic name from Santana do Cariri city.

Type-species: Cariridris bipetiolata, sp. n. (by monotypy)

Diagnosis (Female):

Occiput rounded. Antennae with well differentiated scape, its length smaller than head width at occiput. Second funicular segment smaller than pedicel, which is twice as long as wide. Lateral margins of trunk almost parallel, without evident angulate posterior corners or plates. Petiole relatively long, cylindrical, with no visible node, and with maximum width at midlength, longer than scape and subequal to head width at occiput. Postpetiole more than two times broader than petiole at apex, but subequal to petiole in length, clearly separated from IV abdominal segment (first gastric) by a strong constriction (visible internally and laterally). First gastric segment slightly broader than trunk's broadest portion (near posterior region of pronotum) and as long as the sum of petiole and postpetiole lengths. Femora greatly swollen near the base.

Cariridris bipetiolata Brandão \& Martins-Neto, new species

Etymology: named for the presence of two segments at the waist region.

Holotye (unique): wingless female-impressions and fragments in

limestone. Preserved at M. A. Vulcano, personal collection under no. 293.

Type-locality: Tatajuba Farm, Santana do Cariri $\left(07^{\circ} 11^{\prime} \mathrm{S}, 39^{\circ} 44^{\prime} \mathrm{W}\right)$, Ceará state, Brasil (Fig. 3).

Stratum-typicum: Crato Member, lower unit of the Santana formation (Lower-Cretaceous) Upper Aptian, Araripe Basin, Northeast Brasil, sensu Lima (1978).

Specific diagnosis: Petiole two and a half times longer than broad. Postpetiole broader than long (Fig. 2). Body integument apparently free of long and stiff hairs, different from other insectfossils from the same bed, which show well preserved macrotrichia. Measurements (in mm): left scale length .99; head width (broadest portion) 1.75 ; head width at vertex $=1.67$; visible head length 1.68; pronotum broadest portion 1.46; trunk length on midline 3.80; petiole length 1.15 ; petiole broadest width .43 ; postpetiole 


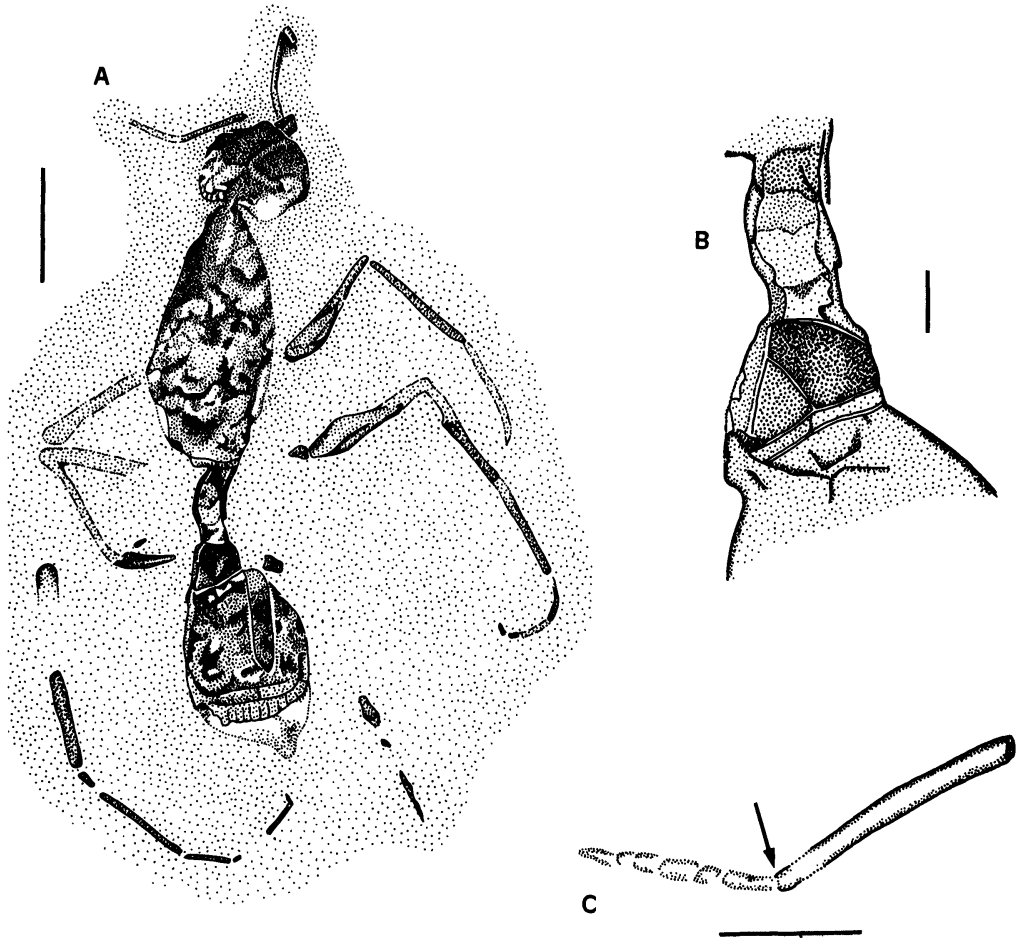

Fig 2. Cariridris bipetiolata, gen. n., sp. n., holotype: A. general habitusdotted lines represent impressions, bracket lines represent inferred outlines. B. detail of the waist region, showing the petiole, postpetiole and the strong constriction between the postpetiole and IV true abdominal segment (first gastric). C. detail of left antenna (scape at right and preserved funicular segments at left); arrow indicates presumed limit between scape and pedicel. Scales bars for $A=2 \mathrm{~mm}, \mathrm{~B}=.5 \mathrm{~mm}$ and $\mathrm{C}=.5 \mathrm{~mm}$.

length .81 , postpetiole broadest width .98 ; IV abdominal segment length on midline 2.08; gaster largest width 1.81; first right femur length 1.92; largest first right femur width at base .35; first right tibia length 1.73; "terminalia" length on midline .98; total length on midline (excluding scapes) 9.78 . 


\section{Discussion}

This fossil ant, the only one found to date in the Araripe Basin, though relatively well-preserved, does not afford a thorough comparison with other Cretaceous formicids. We identify it as a formicid by the presence of a clearly differentiated scape and by the specialized second true abdominal segment (petiole).

Sphecomyrmine fossils, in the sense of Wilson (1987), have the second funicular segment longer than any other funicular segment (but see Wilson, 1985a, for $S$. canadensis), an unusual primary feature in ants. If our interpretation of $C$. bipetiolata left antenna is correct, the first three funicular segments are subequal.

Dr. E. O. Wilson, while reviewing this manuscript in an earlier draft, was kind enough to suggest that Cariridris could be assigned to Myrmeciinae. This subfamily, represented today only by the Australian Myrmecia, also includes the Baltic amber (Oligocene) Prionomyrmex longiceps Mayr, 1868 (worker redescription and male description in Wheeler, 1914), and Ameghinoia piatnitzkyi Viana \& Haedo Rossi, 1957 (systematic position in Burham, 1978), the latter described from three alate females embedded in limestones found near San Carlos de Bariloche, Argentina, probably Lower Miocene or Upper Oligocene.

We conferred generic status to the Santana fossil by the petiolar structure. Cariridris has an almost cylindrical petiole, though we could only observe its lateral margins, while Ameghinoia and Prionomyrmex (by studying figures and photographs provided by authors and not actual specimens) already present a differentiated node, slightly pointed anteriorly and with a concave anterior face. In both, the petiolar maximum width is near the segment apex, while in Cariridris is near the midlength. In Myrmecia the petiole has a completely differentiated node with a strongly concave anterior face and its apex is anteriorly pointed.

The finding of a Lower Cretaceous myrmeciine is important for many reasons, not only for extending its representation to 100 million years before the present. The subfamily Sphecomyrminae was originally represented as the possible stem of the formicoid complex (Wilson et al., 1967). Although Taylor (1978), considered it ancestral to all Formicidae, this seminal position was challenged by Dlusskyi (1987), with whom we concur. With the new evidence on Cariridris at hand, a wholly different concept of the origin of the 


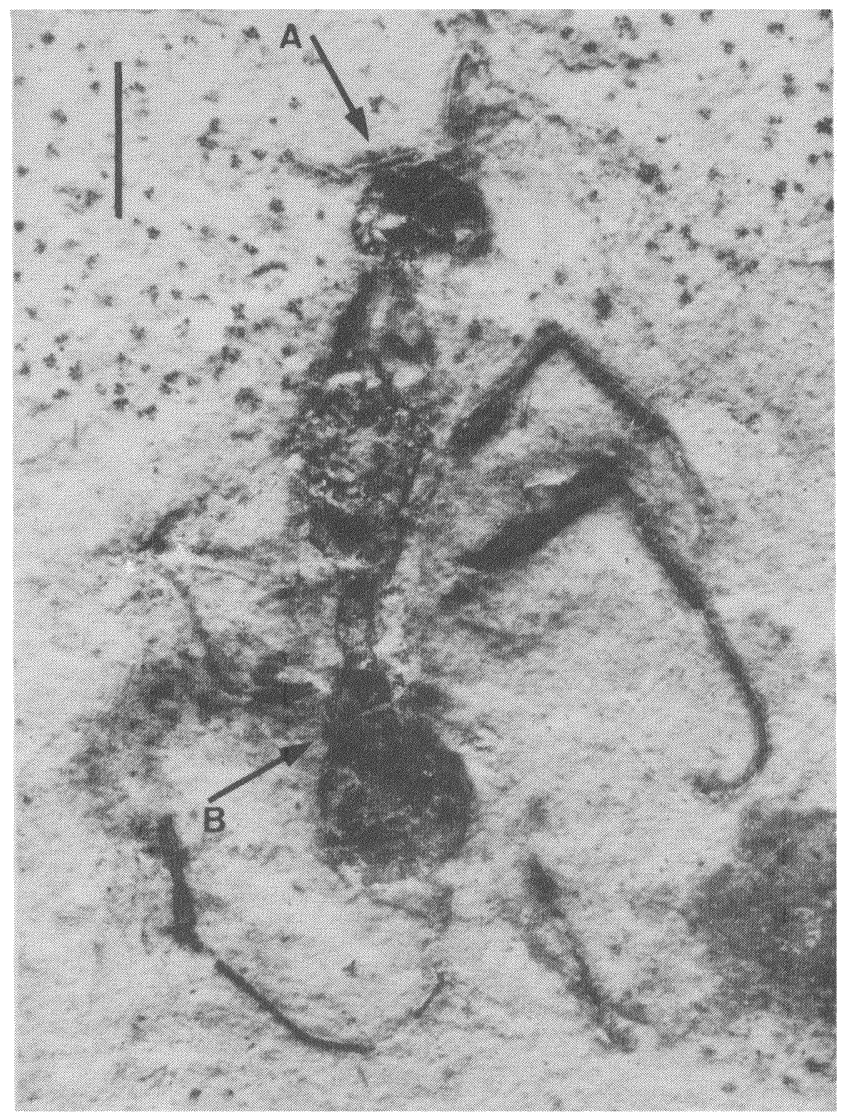

Fig. 3. Cariridris bipetiolata, gen. n., sp. n., holotype. Arrow indicates Ascape of left antenna, B-constriction between postpetiole and first gastric segment (fourth true abdominal segment). Scale bar $=2 \mathrm{~mm}$.

Formicidae emerges, beginning at least in the uppermost Lower Cretaceous, circa 30 millions of years prior to any other evidence. Myrmeciinae occur in a wide distribution, though in lower densities, when compared to modern Formicidae. Even a deposit as rich as the Santana Formation yielded just one fossil ant, contrary to the very rich Oligocene and Miocene deposits.

The last point to be discussed is the possibility of inferring the level of social evolution from fossils. Wilson's (1987) morphometrical criterion is at present the only one to evaluate the probability of 
eusocial versus solitary levels of sociality. He has used head length as a measure of body size as a whole, plotted against the size of the abdomen, adopted as an indicator of reproductive versus nonreproductive status in females. Accepting that the head of $C$. bipetiolata is spherical, we utilized the largest head width as a measure comparable to head length and for the abdomen size we used gaster length (IV abdominal segment plus "terminalia"), adopting Wilson's functional definition. Comparing our measures with those presented by Wilson's figure 1, the specimen of Cariridris bipetiolata agrees with Recent and fossil ant workers, in oppostion to winged Cretaceous formicids and modern wingless aculeate females.

Other evidence for considering the $C$. bipetiolata fossil as a worker is the enlarged prothorax, comparable to modern ant workers' prothoraxes. Other Cretaceous formicid of comparable age so far discovered are interpreted as winged females or males.

\section{SUMMARY}

Cariridris bipetiolata gen. n., sp. n., is described from a single fossil found within a fine-grained, limestone piece from Santana do Cariri (Tatajuba Farm), state of Ceará, Brasil, in the Araripe Basin (Santana Formation-Crato Member-Upper Aptian, Lower Cretaceous). The specimen is interpreted as a worker and the genus as belonging to the Myrmeciinae, possibly representing the oldest undoubted record of an ant. We discuss the phylogenetic implications of this finding.

\section{ACKNOWLEDGMENTS}

This investigation was partially supported by FAPESP and CNPq. Dr. P. E. Vanzolini critically read the manuscript. Sérvio T. P. Amarante kindly took the pictures. Dr. Eva Batista Caldas gave RGMN a most valuable collaboration during his visit to Santana do Cariri. Dr. E. O. Wilson kindly revised the manuscript and gave us important suggestions. 


\section{Literature Cited}

Baroni URBANI, C.

1980a. First description of fossil gardening ants (Amber Collection Stuttgart and Natural History Museum Basel; Hymenoptera: Formicidae. I. Attini). Stuttg. Beitr. Naturk., B, 54: 1-13.

1980b. Anochetus corayi n. sp., the first fossil odontomachiti ant (Amber Collection Stuttgart and Natural History Museum Basel; Hymenoptera: Formicidae. II. Odontomachiti). Stuttg. Beitr. Naturk., B, 55: $1-6$.

1980c. The first fossil species of the Australian ant genus Leptomyrmex in amber from the Dominican Republic (Amber Collection Stuttgart: Hymenoptera, Formicidae. III. Leptomyrmicini). Stuttg. Beitr. Naturk., B, 62: 1-10.

1980d. The ant genus Gnamptogenys in Dominican amber (Amber Collection Stuttgart: Hymenoptera, Formicidae. IV. Ectatommini). Stuttg. Beitr. Naturk., B, 67: 1-10.

Baroni URbani, C. AND E. O. Wilson.

1987. The fossil members of the tribe Leptomyrmicini (Hymenoptera: Formicidae). Psyche, Camb., 94: 1-8.

BROWN JR., W. L.

1954. Remarks on the internal phylogeny and subfamily classification of the family Formicidae. Insectes Soc., Paris, 1: 21-31.

BURHAM, L.

1978. Survey of social insects in the fossil record. Psyche, Camb., 85: 85-133. Campos, D. A.

1986. Primeiro Registro Fóssil de Scorpionoidea na Chapada do Araripe (Cretáceo Inferior), Brasil. Anais Acad. bras. Ciênc., Rio de Janeiro, 58: $135-137$.

Campos, D. A. and A. W. A. Kellner.

1985. Panorama of the flying reptiles study in Brazil and South America. Anais Acad. bras. Ciênc., Rio de Janeiro, 57: 453-466.

Carpenter, F. M. and H. R. Hermann.

1979. Antiquity of sociality in insects. In Hermann, H. R. (ed.) Social Insects. Academic Press, N. Y., vol. 1, p. 81-89.

DLuSSKYi, G. M.

1983. A new family of Upper Cretaceous Hymenoptera: an intermediate link between the ants and the scolioids. Paleont. Journ., Moscow, 0(3): 63-76.

1987. New Formicoidea (Hymenoptera) of the Upper Cretaceous. Paleont. Journ., Moscow, 0(1): 146-150.

Jell, P. A. And P. M. Duncan.

1986. Invertebrates, mainly insects, from the freshwater, lower Cretaceous, Koonwarra Fossil Bed (Korumburra Group), South Gippsland, Victoria. Mem. Ass. austral. Paleontols., 3: 111-205.

Kellner, A. W. A.

1987. Ocorrência de um novo crocodiliano no Cretáceo Inferior da Bacia do Araripe, Nordeste do Brasil. Anais Acad. bras. Ciênc., Rio de Janeiro, 59: $219-232$. 
Kellner, A. W. A. and D. A. Campos.

1987a. Sobre um Novo Pterosauro com crista sagital da Bacia do Araripe, Cretáceo Inferior do Nordeste do Brasil. Anais Acad. bras. Ciênc., Rio de Janeiro, 59: 227 (Abstract).

1987b. Primeira ocorrência de Amphibia (Anura) no Cretáceo Inferior da Bacia do Araripe, Nordeste do Brasil. Anais Acad. bras. Ciênc., Rio de Janeiro, 59: 619 (Abstract).

LiMA, M. R.

1978. Palinologia da Formação Santana (Cretáceo do Nordeste do Brasil). Ph.D. thesis (unpublished), Inst. Geociênc. USP, 335 p.

1979. Considerações sobre a subdivisão estratigráfica da Formação Santana, Cretáceo do Nordeste do Brasil. Revta. bras. Geoc., S. Paulo, 9: 116-121.

1981. Palinologia do Mesozóico brasileiro: uma síntese. In Comité Sudamericano del Jurássico y Cretácico; Cuencas sedimentarias del Jurássico y Cretácico de América del Sur, B. Aires, 2: 445-460.

Lima, M. R. ANd J. A. J. Perinotto.

1984. Palinologia de sedimentos da parte superior da Formação Missão Velha, Bacia do Araripe. Geociências, S. Paulo, 3: 67-76.

LuTz, $\mathrm{H}$.

1986. Eine neue Unterfamilie der Formicidae (Insecta: Hymenoptera) aus den mittel-eozänen Ölschiefer der "Grube Messel" bei Darmstadt (Deutschland, S-Hessen). Senckenberg. leth., Frankfurt, 67: 177-218.

\section{MARTINS-Neto, R. G.}

1987a. Primeiro registro de Decapode na Formação Santana, Bacia do Araripe (Cretáceo Inferior), Nordeste do Brasil. Ciênc. Cult., S. Paulo, 39: 406-410.

1987b. A Paleoentomofauna Brasileira: Estágio atual do conhecimento. An. $X$ Congr. brasil. Paleont., 2: 567-591, Rio de Janeiro.

in press. Insecta. In Volkheimer, W. (org.) Stratigraphic Range of Cretaceous Mega and Micro Fossils of Latin America, Cambridge Univ. Press.

Martins-Neto, R. G. and A. W. A. Kellner.

1988. Primeiro Registro de Pena na Formação Santana, Cretáceo Inferior da Bacia do Araripe, Nordeste do Brasil. Anais Acad. bras. Ciênc., Rio de Janeiro, 60(1): 61-68.

MAYR, G.

1868. Die Ameisen des baltischen Bernsteins. Physik.-ökon. Ges., Königsberg, 1: 1-102.

PoPOFF, M.

1988. Du Gondwana a l'Atlantique Sud: les connexions du fossé de la Bénoué avec les bassins du Nord-Est brésilien jusqu'à l'ouverture du golfe de Guinée au Crétacé Inférieur. J. Afr. Earth Sci., Elmsford, 7(2): 409-431.

TAYLOR, R. W.

1978. Nothomyrmecia macrops: A living-fossil ant rediscovered. Science,

N. Y., 201: 979-985. 
UNWIN, D. M.

1988. New pterosurs from Brasil. Nature, Lond., 331: 398-399.

Viana, M. J. AND J. A. HaEdo Rossi

1957. Primer Hallazgo en el Hemisferio Sur de Formicidae Extinguidos y Catalogo Mundial de los Formicidae Fosiles. Ameghiniana, Buenos Aires, 1(1-2): 108-113.

WHEELER, W. M.

1914. The ants of the Baltic amber. scrift. Physik.-ökon. Ges., Königsberg, 55: $1-142$.

WILSON, E. O.

1985a. Ants from the Cretaceous and Eocene amber of North America. Psyche, Camb., 92: 205-216.

1985b. Ants of the Dominican amber (Hymenoptera: Formicidae). 1. Two new myrmicine genera and an aberrant Pheidole. Psyche, Camb., 92: 1-9.

1985c. Ants of the Dominican amber (Hymenoptera: Formicidae). 2. The first fossil army ants. Psyche, Camb., 92: 11-16.

1985d. Ants of the Dominican amber (Hymenoptera: Formicidae). 3. The subfamily Dolichoderinae. Psyche, Camb., 92: 17-37.

1985e. Ants of the Dominican amber (Hymenoptera: Formicidae). 4. A giant ponerine in the genus Paraponera. Israel J. Ent., Tel-Aviv, 19: 197-200.

1987. The earliest known ants: an analysis of the Cretaceous species and an inference concerning their social organization. Paleobiol., Menlo Park, 13: 44-53.

Wilson, E. O., F. M. Carpenter and W. L. Brown, Jr.

1967. The first Mesozoic ants, with the description of a new subfamily. Psyche, Camb., 74: 1-19. 

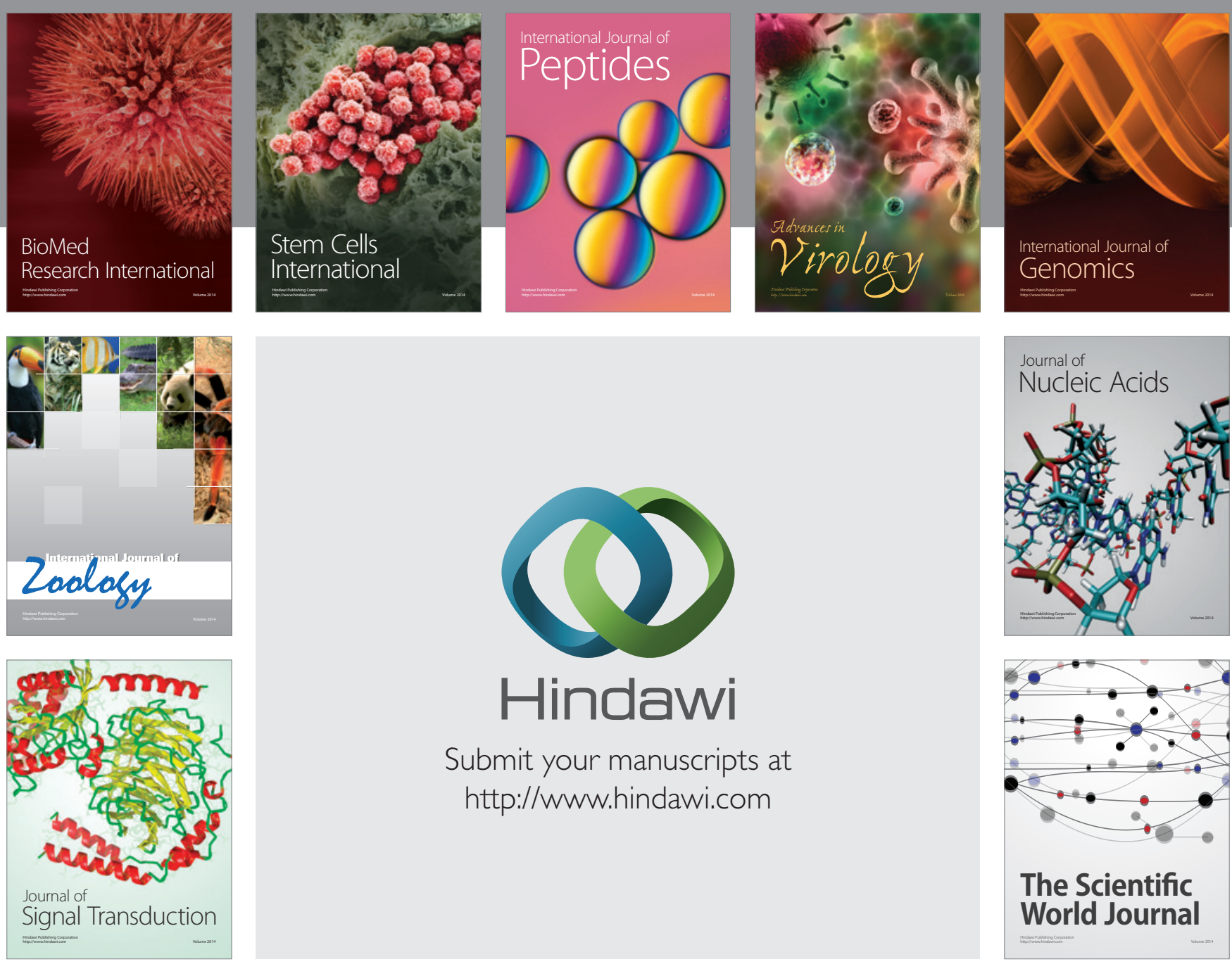

Submit your manuscripts at

http://www.hindawi.com
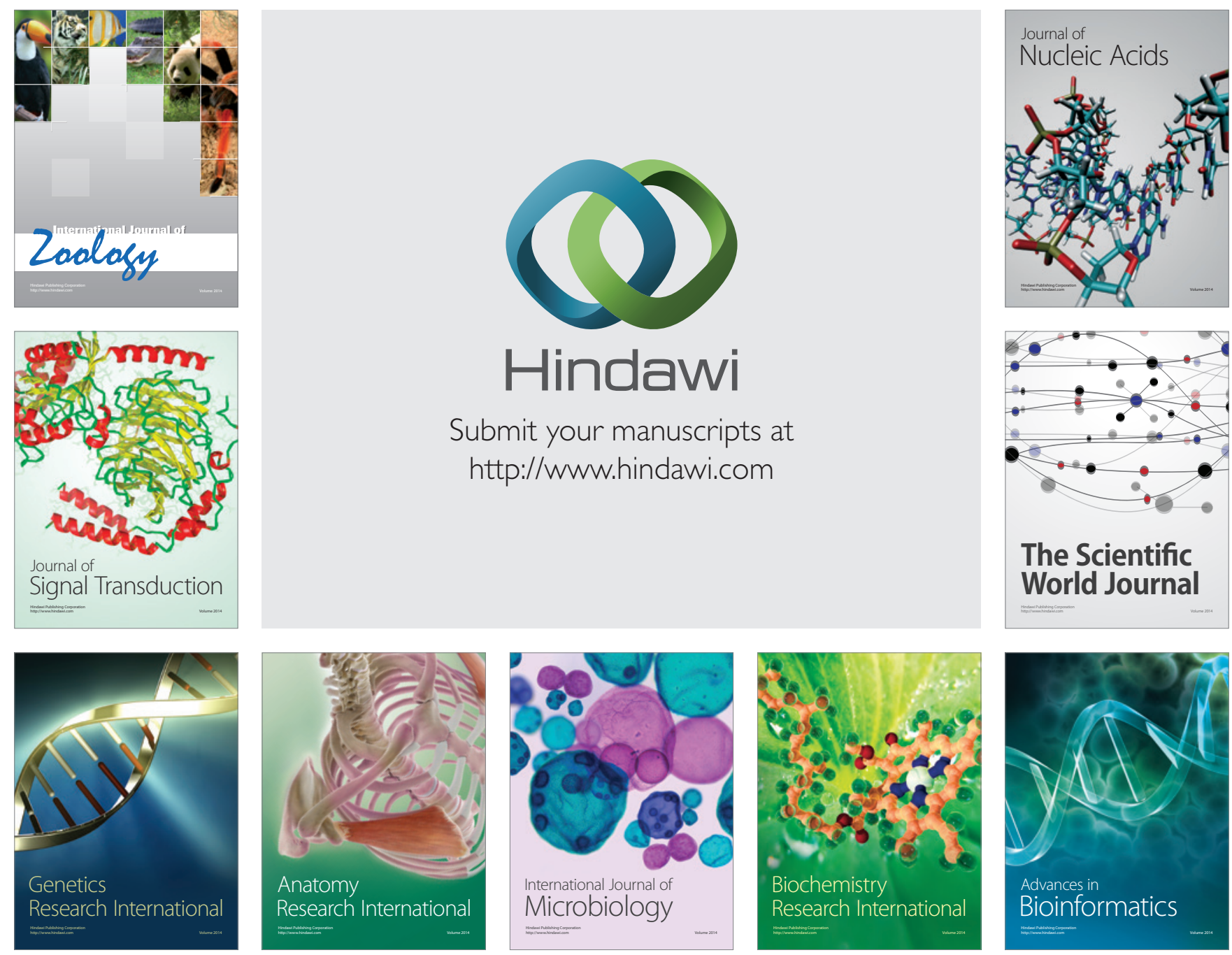

The Scientific World Journal
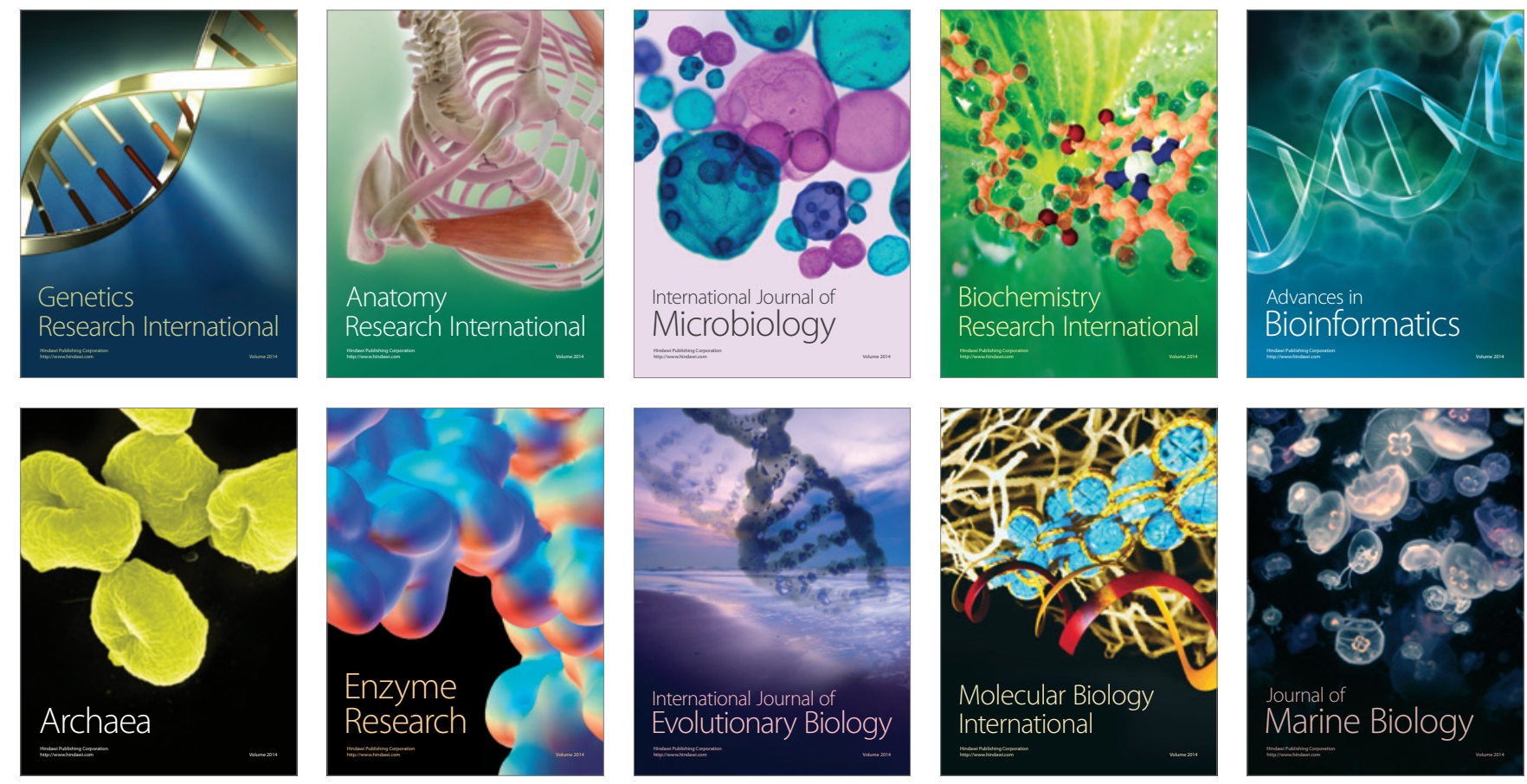